\title{
PEMANFAATAN MEDIA SOSIAL DALAM KEGIATAN BELAJAR MENGAJAR PADA MASA COVID-19 DI MI AL-IMAN WAY JEPARA
}

\author{
Dewi Tri Santi \\ dewitricandi24@gmail.com
}

STAI Darussalam Lampung

\begin{tabular}{c|c|c}
\hline \hline Received: & Revised: & Aproved: \\
12/07/2020 & $14 / 08 / 2020$ & $05 / 10 / 2020$ \\
\hline \hline
\end{tabular}

\begin{abstract}
This article aims to examine the use of social media at MI Al-Iman Way Jepara during the Covid-19 pandemic. The data from this study were obtained from observation, interviews, and documentation. The results of this study indicate that social media provides benefits to students, parents, teachers in online learning activities. Barriers to the use of social media occur because the facilities and infrastructure at educational institutions are not fulfilled. In addition, not all social media can be used by teachers and parents, given their low technological skills. This shows that the use of social media as a medium and learning resource in the midst of this pandemic has not been optimal. The positive contribution of this research to education in Indonesia is to provide information to educational institutions to be able to anticipate the COVID-19 pandemic by utilizing social media as a medium for learning online by paying attention to the level of understanding of its users.
\end{abstract}

Keywords: Covid-19, Social Media, Learning

\begin{abstract}
Abstrak
Artikel ini bertujuan untuk mengkaji tentang pemanfaatan media sosial di MI Al-Iman Way Jepara pada masa pandemi Covid-19. Data dari penelitian ini diperoleh dari observasi, wawancara, dan dokumentasi. Hasil penelitian ini menunjukkan bahwa media sosial memberikan manfaat kepada siswa, orang tua, guru dalam kegiatan belajar secara daring. Hambatan pemanfaatan media sosial terjadi karena tidak terpenuhinya sarana dan prasarana pada lembaga pendidikan. Selain itu tidak semua media sosial dapat dimanfaatkan oleh guru dan orang tua, mengingat kemampuan teknologi mereka yang masih rendah. Hal ini menunjukkan bahwa pemanfaatan media sosial sebagai media dan sumber belajar di tengah pandemi ini belum maksimal. Kontribusi positif dari penelitian ini terhadap pendidikan di Indonesia adalah memberikan informasi kepada lembaga pendidikan untuk dapat mensiasati pandemi
\end{abstract}


covid19 dengan memanfaatkan media sosial sebagai media untuk belajar secara daring dengan memperhatikan tingkat pemahaman penggunanya.

\section{Kata Kunci: Covid-19, Media Sosial, Pembelajaran}

\section{A. Pendahuluan}

Pada awal tahun 2020, dunia digemparkan dengan merebaknya virus baru yaitu corona virus jenis baru (SARS-CoV-2) dan penyakitnya di sebut Corona Virus Disease 2019 (COVID-19). Diketahui asal mula virus ini berasal dari Wuhan, Tiongkok. Ditemukan pada akhir Desember 2019. ${ }^{1}$ organisasi Kesehatan Duni (WHO) mendeklarasikan wabah Coronavirus 2019-2020 sebagai Kesehatan Masyarakat Darurat Internasional (PHEIC) pada 30 Januari 2020, dan pandemic pada 11 Maret 2020. Wabah penyakit ini begitu sangat mengguncang masyarakat dunia, mengingat hampir 200 Negara di Dunia terjangkit oleh virus Covid-19 pun dilakukan oleh pemerintah di Negara-ngara di dunia guna memutus rantai penyebaran virus Covid-19 ini, yang disebut dengan istilah lockdown dan social distancing. ${ }^{2}$

Pandemi global saat ini terjadi pula di Indonesia membuat banyak pihak berupaya ikut berperan serta dalam mengatasi. Oleh sebab itu, para dokter umum dan spesialis angkat bicara bersama guna member penjelasan singkat kepada masyarakat maupun imbauan agar menjaga kebersihan diri dan lingkungan sekaligus tidak banyak keluar rumah. ${ }^{3}$

Pandemi COVID-19 merupakan musibah yang memilukan seluruh penduduk bumi. Seluruh segmen kehidupan manusia di bumi terganggu, tanpa kecuali pendidikan. Banyak Negara memutuskan menutup sekolah, perguruan tinggi maupun universitas, termasuk Indonesia. Krisis benar-benar datang tiba-tiba, pemerintah di belahan bumi manapun termasuk Indonesia harus mengambil

${ }^{1}$ Yuliana, "Wellness and Healthy Magazine,” Corona Virus Diseases (Covid-19) Sebuah Tinjauan Literatur. No.1 (2020):187.

${ }^{2}$ Eman Supriatna, "Salam; Jurnal Sosial \& Budaya Syar-I FSH UIN Syarif Hidayatullah Jakarta,” Wabah Corona Virus Disease Covid-19 dalam Pandangan Islam. No.6 (2020): 556

3 Adip Rifqi Setiawan, "Edukatif: Jurnal Ilmu Pendidikan,” Lembar Kegiatan Literasi Saintifik untuk Pembelajaran Jarak Jauh Topik Penyakit Coronavirus 2019 (COVID-19), No.1 (2020): 29. 
keputusan yang pahit menutup sekolah untuk mengurangi kontak orang-orang secara masif dan untuk menyelamatkan hidup atau tetap harus membuka sekolah dalam rangka survive para pekerja dalam menjaga keberlangsungan ekonomi. ${ }^{4}$

UNESCO (United Nations Educations, Scientific, and Curtural Organization) pada 4 Maret 2020 menyarankan penggunaan pembelajaran jarak jauh dan membuka platform pendidikan yang dapat digunakan sekolah dan guru untuk menjangkau peserta didik dari jarak jauh dan membatasi gangguan pendidikan. ${ }^{5}$

Begitu pula yang dikemukakan oleh Preseiden Joko Widodo pada tanggal 15 Maret 2020 melalui akun You Tube resmi Sekretariat Presiden bahwa Presiden Joko Widodo (Jokowi) memerintahkan kepada para kepala daerah untuk segera membuat kebijakan agar pelajar sekolah dan mahasiswa tidak ke gedung sekolah (ruang kelas) atau kampus selama pandemi COVID-19 ini. Sehingga, kegiatan belajar mengajar di dalam gedung sekolah dan perguruan tinggi untuk sementara waktu ditiadakan. ${ }^{6}$

Kementerian Pendidikan dan Kebudayaan (Kemendikbud) kemudia menyikapi kondisi tersebut dengan membuat sejumlah kebijakan. Mulai dari realokasi anggaran Kemendikbud untuk penanganan penyebaran Covid-19 berupa pemberian komunikasi, informasi, dan edukasi terkait Covid-19, peningkatan kapasitas dan kapabilitas rumah sakit pendidikan (RSP), pelaksanaan rapid test di lima RSP, dan pengadaan bahan habis pakai. ${ }^{7}$

Korban akibat wabah covid-19, tidak hanya pendidikan di tingkat Sekolah Dasar/Madrasah Ibtidaiyah, Sekolah Menengah Pertama/Madrasah Tsanawiyah, dan Sekolah Menengah Atas/Madrasah Aliyah, tetapi juga perguruan tinggi. ${ }^{8}$

${ }^{4}$ Rizqon Halal Syah Aji, "Salam; Jurnal Sosial \& Budaya Syar-I FSH UIN Syarif Hidayatullah Jakarta,” Dampak Covid-19 pada Pendidikan di Indonesia: Sekolah, Keterampilan, dan Proses Pembelajaran. No.5 (2020): 396.

5 Adip Rifqi Setiawan, “Edukatif: Jurnal Ilmu Pendidikan,” Lembar Kegiatan Literasi Saintifik untuk Pembelajaran Jarak Jauh Topik Penyakit Coronavirus 2019 (COVID-19),... h. 29.

${ }^{6}$ Dikutib dari laman You Tube akun Sekretarian Presiden http://youtu.be/S-z9yefp-lk Diakses Tanggal 24 Sepetember 2020.

7 Keputusan Bersama 4 Menteri, Panduan Penyelenggaraan Pembelajaran Pada Tahun Ajaran 2020/2021 dan Tahun Akademik 2020/2021 di Masa Pandemi Coronavirus Disease 2019 (Covid-19), Kementerian Pendidikan dan Kebudayaan: Jakarta Pusat, Tahun 2020. Hal 3.

${ }^{8}$ Agus Purwanto, Rudy Pramono, Masduki Asbari, Priyono Budi Santoso, Laksmi Mayeti 
Sehingga situasi ini menuntut para guru dan siswa belajar melalui jaringan internet dari platform yang sudah disediakan. ${ }^{9}$

Di beberapa daerah proses pembelajaran dari rumah telah berlangsung sejak tanggal 16 Maret 2020 dan diperpanjang dengan mempertimbangkan situasi di masing-masing daerah. Dari sumber daya manusia, pendidik maupun peserta didik ada yang memang sudah siap. Tetapi banyak pula yang terpaksa harus siap menghadapi pembelajaran yang biasanya dilaksanakan secara tatap muka berubah menjadi sistem belajar jarak jauh secara daring. ${ }^{10}$

E-education, istilah ini mungkin masih asing bagi masyarakat Indonesia. Eeducation (Pendidikan Elektronik) adalah sebutan untuk penggunaan IT di bidang Pendidikan. Internet membuka sumber informasi yang tadinya sulit diakses. ${ }^{11}$

Masyarakat Indonesia sendiri terbilang cukup mudah beradaptasi dengan jenis-jenis media sosial yang baru. Namun berdasarkan laporan digital tahunan yang dikeluarkan oleh We Are Social dan Hootsuite pada Januari 2018, ada empat kanal media sosial yang paling banyak digunakan masyarakat Indonesia, yaitu You Tube, Facebook, Instagram, dan Twitter. ${ }^{12}$

Pada masa pandemi Covid-19 ini, Madrasah Ibtidaiyah Al-Iman Way Jepara dalam proses pembelajarannya juga mengikuti arahan dari Surat Edaran Kemendikbud tersebut, yaitu melalui pembelajaran daring/jarak jauh, dengan cara memanfaatkan media sosial yang ada, seperti Facebook, Youtube, Whatsapp, Zoom, Ruang Guru, dan platform dari Kemenag yaitu E-Learning. Para guru dan orang tua dituntut agar mampu memanfaatkan media sosial dalam proses siswa Belajar dari Rumah. Sehingganya dalam proses pelaksanaannya masih terdapat kendala. Sebab, tidak semua siswa terbiasa belajar melalui online. Apalagi guru dan

Wijayanti, Choi Chi Hyun, Ratna Setyowati Putri, “EduPsyCouns Jurnal,” Stusi Eksplorasi Dampak Pandemi Covid-19 Terhadap Proses Pembelajaran Online di Sekolah Dasar 2, No. 1 (2020): 3.

${ }^{9}$ Nurkholis, “Jurnal OGSD”, Dampak Pandemi Novel-Corona Virus Disiase (Covid-19) Terhadap Psikologi dan Pendidikan Serta Kebijakan Pemerintah 6, No. 1 (2020): 40.

${ }^{10}$ Fieka Nurul Arifa, "Info Singkat," Tantangan Pelaksanaan Kebijakan Belajar Dari Rumah 12, No. 7 (2020): 14.

${ }^{11}$ Yulita Pujilestari, :Adalah: Buletin Hukum \& Keadilah,” Dampak Positif Pembelajaran Online Dalam Sistem Pendidika Indonesai Pasca Pandemi Covid-19 4, No. 1 (2020): 51.

${ }^{12}$ Rosalia Niken Widiastuti, Memaksimalkan Penggunaan Media Sosial dalam Lembaga Pemerintah, (Jakarta Pusat Direktorat Jenderal Informasi dan Komunikasi Publik, Kementerian Komunikasi dan Informasi, 2018), Hal. 9. 
orang tua masih banyak belum mahir menggunakan teknologi internet dan media sosial, terutama di daerah pedesaan seperti di Madrasah Ibtidaiyah Al-Iman Way Jepara. Terdapat masih banyak orang tua yang tidak memiliki smarphone/gadged yang sudah support platform tersebut. Tujuan dari penelitian ini adalah untuk mengetahui bagaimana pemanfaatan media sosial dalam kegiatan belajar mengajar di masa panemi Covid-19 MI Al-Iman Way Jepara.

\section{B. Pembahasan}

\section{Kajian Teori}

\section{a. Covid-19}

Coronavirus adalah virus RNA dengan ukuran partikel 120-160 nm. Virus ini utamanya menginfeksi hewan, termasuk diantaranya adalah kelelawar dan unta. Sebelum terjadinya wabah Covid-19, ada 6 jenis coronavirus yang dapat menginfeksi manusia, yaitu alphacoronavirus 229E, alphacoronavirus NL63, betacoronavirus OC43, betacoronavirus HKU1, Severe Aute Respiratory Illness Coronavirus (SARS-CoV), dan Middle East Respiratory Syndrome Coronavirus (MERS-CoV). Coronavirus yang menjadi etiologi Covid-19 termasuk dalam genus betacoronavirus. ${ }^{13}$

Coronavirus sensitive terhadap panas dan secara efektif dapat diinaktifkan oleh desinfektan mengandung klorin, pelarut lipid dengan suhu $56^{\circ} \mathrm{C}$ selama 30 menit, eter, alkohol, asam perioksiasetat, detergen, non-ionik, formalin, oxidizing agen dan kloroform. Klorheksidin tidak efektif dalam menonaktifkan virus. ${ }^{14}$

Penyakit Coronavirus 2019 (Covid-19) adalah penyakit menular yang disebabkan oleh sindrom pernapasan akut Coronavirus 2 (SARS-CoV-2). Penyakit ini pertama kali diidentifikasi pada Desember 2019 di Wuhan, ibu

${ }^{13}$ Adityo Susilo, C. Martin Rumende, Ceva W Pitoyo, Widayat Djoko Santoso, Mira Yulianti, Herikurniawan, Robert Sinto, Gurmeet Singh, Leonard Nainggolan, Erni J Nelwan, Lie Khie Chen, Alvina Widhani, Edwin Wijaya, Bramantya Wicaksana, Maradewi Maksum, Firda Annisa, Chyntia OM Jasirwan, Evy Yunihastuti, “Jurnal Penyakit Dalam Indonesia,” Coronavirus Disease 2019: Tinjauan Literatur Terkini 7, No. 1 (2020): 46.

${ }^{14}$ Yulina, "Wellness and Healthy Magazine," Corona Virus Diseases (Covid-19), Sebuah Tinjauan Literatur, No. 1 (2020): 188-189. 
kota provinsi Hubei, China, dan sejak itu menyebar secara global, mengajibatkan pandemi coronavirus 2019-2020 yang sedang berlangsung. ${ }^{15}$

Gejala Covid-19 umumnya berupa demam $38^{\circ} \mathrm{C}$, batuk kering, dan sesak napas serta dampak paling buruk untuk manusia ialah kematian. ${ }^{16}$

\section{b. Media Sosial}

Kata media berasal dari bahasa Latin medius yang secara harfiah berarti 'tengah', 'perantara'. Dalam bahasa Arab, media adalah perantara atau pengantar pesan dari pengirim kepada penerima pesan. Gerlach \& Ely mengatakan bahwa media apabila dipahami secara garis besar adalah manusia, materi, atau kejadian yang membangun kondisi yang membuat siswa mampu memperoleh pengetahuan, keterampilan, atau sikap. Dalam pengertian ini, guru, buku teks, dan lingkungan sekolah merupakan media. ${ }^{17}$

Secara sederhana, istilah media biasa dijelaskan sebagai alat komunikasi sebagaimana definisi yang selama ini diketahui. Terkadang media ini cenderung lebih dekat terhadap sifatnyayang massa karena terlihat dari berbagai teori yang muncul dalam komunikasi massa. Sedangkan kata sosial dalam media sosial secara teori semestinya didekati oleh ranah sosiologi. Kata sosial secara sederhana merujuk pada relasi sosial. Relasi sosial itu sendiri bisa dilihat dalam kategori aksi sosial dan relasi sosial. ${ }^{18}$

Social media atau dalam bahasa Indonesia disebut media sosial adalah media yang didesain untuk memudahkan interaksi sosial yang bersifat interaktif atau dua arah. Media sosial yang berbasis pada teknologi internet mengubah pola penyebaran informasi dari yang sebelumnya bersifat satu menjadi banyak audiens. ${ }^{19}$

${ }^{15}$ Eman Supriatna, "Salam: Jurnal Sosial \& Budaya Syar-I FSH UIN Syarif Hidayatullah Jakarta,” Wabag Corona Virus Disease Covid 19 dalam Padangan Islam, No. 6 (2020): 557.

${ }^{16}$ Adip Rifqi Setiawan, "Edukatif: Jurnal Ilmu Pendidikan,” Lembar Kegiatan Literasi Saintifik untuk Pembelajaran Jarak Jauh Topik Penyakit Coronavirus 2019 (COVID-19), No. 2 (2020): 29.

${ }^{17}$ Azhar Arsyad, Media Pembelajaran, RajaGrafindo Persada: Jakarta, Tahun 2013. Hal. 3.

18 Muhammad Hanafi, “JOM FISIP,” Pengaruh Penggunaan Media Sosial, Facebook Terhadap Motivasi Belajar Mahasiswa FISIP Universitas Riau, No.2 (2016): 5.

${ }^{19}$ Donni Juni Priansa, Komunikasi Pemasaran Terpadu, Pustaka Setia: Bandung, Tahun 2017, Hal 358. 
Van Dijk dalam Nasrullah menyatakan bahwa media sosial adalah platform media yang menfokuskan pada eksistensi penggunaan yang menfasilitasi mereka dalam beraktifitas maupun berkolaborasi. Karena itu media sosial dapat dilihat sebagai medium (fasilitator) online yang menguatkan hubungan antar pengguna sekaligus sebuah ikatan sosial. Menurut Nasrullah dalam bukunya, media sosial beranjak dari pemahaman bagaimana media tersebut digunakan sebagai sarana sosial di dunia virtual. Media-media sosial seperti facebook, twitter, whatsapp, Line, Path, Instagram, Youtube, dan lainnya merupakan situs sosial interaktif yang membuat penggunananya dapat saling bertukar dan berbagi pesan, menambah teman hingga membentuk jaringan sosial di dunia virtual. ${ }^{20}$

\section{c. Manfaat Media Sosial}

Adapun manfaat penggunaan media sosial secara umum diantaranya yaiut:

a) Media komunikasi digital. Media sosial membantu pengguna berinteraksi dengan siapa pun dan kapan pun melalui koneksi internet.

b) Sarana pembelajaran dan pengembangan diri. Melimpahnya informasi di dunia maya menjadikan media sosial sebagai salah satu sarana pembelajran dan pengembangan diri.

c) Media hiburan. Konten yang tersebar di media sosial ini sangatlah beragam dan tidak sedikit masyarakat yang menjadikan media sosial sebagai media hiburan dalam aktivitas sehari-hari.

d) Membuka lapangan pekerjaan. Ada banyak sekali pekerjaan yang lhir dari perkembangan mdia sosial. Sebut saja pembuat konten, penulis artikel hingga berjualan adalah contok pekerjaan yang dapat dilakukan dengan bantuan media sosial.

${ }^{20}$ Cut Nadya B, Rista Destiwati, “Jurnal Manajemen Komunikasi,” Pola Komunikasi Virtual Grup Percakapan Komunitas Hamur"HAMURinspiring” Di Media Sosial Line, No.1 (2018): 35-36. 
e) Media komunikasi digital mirip dengan kegunaan media sosial bagi individu, saat ini hampir semua organisasi memanfaatkan media sosial sebagai saluran komunikasi digital mereka dengan masyarakat.

f) Media pemasaran. Daya jangkau media sosial yang sangat luas menjadikan media sosial sebagai salah satu sarana utama dalam peningkatan penjualan dan pemasaran digital saat ini. ${ }^{21}$

Selanjunya, manfaat media sosial di dalam dunia pendidikan yang telah diungkapkan oleh Soekarwati, di antaranya yaitu:

a) Tersedia fasilitas e-Moderating, di mana pendidikan dan peserta didik dapat berkomuniasi secara mudah melalui fasilitas internet secara regular atau kapan saja kegiatan komunikasi itu dilakukan dengan tanpa dibatasi oleh jarak, tampat, dan waktu.

b) Pendidik dan peserta didik dapat menggunakan bahan ajar atau petunjuk belajar yang tersetruktur dan terjadwal melalui internet, sehingga keduanya bisa saling menilaiberapa jauh bahan ajar dipelajari.

c) Peserta didik dapat belajar atau me-review bahan ajar setiap saat dan dimana saja kalau diperlukan mengingat bahan ajar tersimpan di dalam computer.

d) Bila peserta didik memerlukan tambahan informasi yang berkaitan dengan bahan yang dipelajari, ia dapat melakukan akses di internet secara lebih mudah.

e) Baik pendidik maupun peserta didik dapat melakukan diskusi melalui internet yang dapat diikuti oleh sejumlah peserta, sehingga menambah ilmu pengetahuan dan wawasan yang lebih luas.

f) Berubahnya peran peserta didik yang biasanya pasif menjadi aktif.

g) Relatif lebih efisien. Misalnya bagi mereka yang tinggal jauh dari pendidikan tinggi, atau sekolah konvensional, bagi mereka yang sibuk

${ }^{21}$ Rosalia Niken Widiastuti, Memaksimalkan Penggunaan Media Sosial dalam Lembaga Pemerintah...10-11. 
bekerja, bagi mereka yang bertugas di kapal, di luar negeri, dan sebagainya. $^{22}$

\section{Metode Penelitian}

Jenis penelitian ini adalah penelitian kualitatif dengan menggunakan metode deskriptif. Menurut Moleong dan Sugiono penelitian kualitatif dengan metode deskriptif ini adalah penelitian yang dilakukan tidak menggunakan angka-angka. Penelitian kualitatif ini mengutamakan kedalaman penghayatan terhadap interaksi antar konsep yang dikaji secara empiris. ${ }^{23}$

Sumber data utama dalam penelitian kualitatif yaitu kata-kata dan tindakan, sisanya adalah data tambahan seperti dokumen dan data lainnya. ${ }^{24}$ Metode penelitian ini akan mencoba mencari tahu pemanfaatan media sosial di tengah pandemic Covid-19 MI Al-Iman Way Jepara.

Instrument yang digunakan dalam penelitian ini adalah peneliti sendiri dibantu dengan alat pengumpul data yaitu hasil wawancara dengan responden, dokumen sekolah, dan hasil belajar siswa.

Metode pengumpulan data primer yaitu dengan wawancara tersetruktur yang dilakukan oleh peneliti secara langsung. Adapaun yang menjadi narasumber diantaranya yaitu Kepala Madrasah, Dewan Guru, wali murid, dan siswa. Sedangkan data sekunder yaitu hasil publikasi terhadap pemanfaatan media sosial yang telah diungah di media sosial seperti Facebook dan di share di whatsapp oleh dewan guru atau salah satu dari pihak sekolah.

22 Deni Darmawan, Pengembangan E-Learning Teori dan Desain, Remaja Rosdakarya: Bandung, Tahun 2016, Hal. 31-32.

23 Abdul Istiqlal, “Jurnal Kepemimpinan dan Pengurusan Sekoalh,” Manfaat Media Pembelajaran dalam Proses Belajar dan Mengajar Mahasiswa di Perguruan Tinggi, No. 2 (2018): 141.

24 Zul Azmi, Abdillah Arif N, Wardayani, “Akuntabilitas: Jurnal Ilmu Akuntasi,” Memahami Penelitian Kualitatif dalam Akuntansi, No. 1 (2018): 165. 


\section{Pembahasan Hasil Penelitian}

\section{Pemanfaatan Media Sosial oleh Murid dalam Kegiatan Belajar di tengah Wabah Covid-19}

Proses pembelajaran di sekolah merupakan alat kebijakan publik terbaik sebagai upaya peningkatan pengetahuan dan skill. Selain itu banyak siswa menganggap bahwa sekolah adalah kegiatan yang sangat menyenangkan, mereka bisa berinteraksi satu sama lain. Sekolah dapat meningkatkan keterampilan sosial dan kesadaran kelas sosial siswa. Sekolah secara keseluruhan adalah media interaksi antar siswa dan guru untuk meningkatkan kemampuan integensi, skill, dan rasa kasih sayang diantara mereka. ${ }^{25}$

Di tengah pandemi Covid-19 ini pembelajaran jarak jauh (dari rumah) sangat diperlukan guna memutus rantai penyebaran virus tersebut dan hal itu sesuai dengan protokol Kemendikbud dalam (SE) Nomor 4 Tahun 2020. Pembelajaran jarak jauh/dari rumah diperlukan media yang dapat menunjang terlaksananya proses pembelajaran tersebut yaitu dengan memanfaatkan media sosial yang berkembang saat ini.

Pemanfaatan internet dalam pembelajaran diharapkan dapat merangsang siswa untuk belajar secara lebih mandiri serta berkelanjutan sesuai dengan kecakapan serta potensi alami yang dimiliki. Pengembangan kreativitas serta kemandirian peserta didik juga terbuka sangat lebar dengan menjadikan internet sebagai sebuah sistem pembelajaran baru.

Di tengah kondisi seperti ini, yang mengharuskan segala jenis aktivitas dilakukukan di dalam rumah termasuk proses belajar mengajar, dalam memanfaatkan media sosial dalam proses pemebelajarannya yaitu adanya harapan besar bahwa pemanfaatan media sosial tersebut tidak hanya sebatas pada kondisi saat ini melainkan lebih dari itu yaitu agar terbentuknya sifat kemandirian siswa dalam hal belajar dan tidak terlalu bergantung sepenuhnya kepada guru.

${ }^{25}$ Rizqom Halal Syah Aji, "Salam: Jurnal Sosial \& Budaya Syar-I,” Dampak Covid-19 pada Pendidikan di Indonesia: Sekolah, Keterampilan, dan Proses Pembelajaran. No.5 (2020): 359. 
Dalam praktiknya, pemanfaatan media sosial belum sepenuhnya dirasakan oleh siswa. Hanya siswa tertentu saja yang dapat memanfaatkan media sosial dalam proses pembelajaran dari rumah, yaitu siswa yang memiliki sarana memadai dan siswa yang memiliki motivasi dalam belajar.

Dalam sebuah wawancara dengan seorang guru, terdapat penjelasan terkait pemanfaatan media sosial dalam proses pembelajaran jarak jauh, yaitu:

"Rata-rata siswa yang sekolah di MI Al-Iman bukan dari mereka yang melek teknologi. Pemahaman akan media sosial hanya sebatas pada kebutuhan primer saja, seperti menelfon dan mengirim pesan. Pengembangan media sosial belum pada pemanfaatan dalam pembelajaran. Hal itu karena sarana dan prasarana yang belum memadai serta jaringan internet yang masih lemah. ${ }^{26}$

Dia menambahkan:

"Selebih siswa kami yang notabene siswa sekolah dasar, mereka belum sepenuhnya mengetahui kegunaan media sosial. Harus ada bimbingan dari orang tua."

Dalam waktu tertentu, peneliti juga melakukan wawancara dengan wali murid:

"Sejak belajar dari rumah ini dimulai, anak saya belum satu kalipun belajar dengan menggunakan media internet, bahkan fasilitas sudah saya penuhi. Sehingga ketika ada tugas dari guru maka saya yang mengerjakan tugas tersebut." 27

Namun terdapat juga siswa yang benar-benar memanfaatkan media sosial ketika belajar secara tatap muka belum dimulai. Seperti siswa MI AlIman Kelas V yang bernama M. Irfan Afandi. Meskipun terkendala dengan saran dan prasarana yang kurang menunjang, namun dengan adanya media sosial, dia dapat memanfaatkan itu untuk menambah ilmu pengetahuannya dan dia dapat berkomunikasi dengan dewan guru. Semangat M. Irfan Afandi dalam belajar selama pandemi ini tidak surut. Ia tetap semangat belajar yaitu dengan senantiasa memanfaatkan media sosial. Dia juga selalu mengerjakan

\footnotetext{
${ }^{26}$ Hasil Wawancara dengan Bapak Bonari pada tanggal 25 Agustus 2020 pukul 09.00.

${ }^{27}$ Hasil Wawancara dengan Ibu Komariah pada tanggal 25 Agustus 2020 pukul 10.30.
} 
tugas dari guru. Bahkan dia merasa ilmunya berkembang lantaran dia dapat mencari ilmu yang tidak ada di buku pelajaran di media sosial. Dalam sebuah wawancara yang penulis lakukan dengan orang tua siswa, penulis berusaha merangkum percakapan itu dalam sebuah uraian. Sekurangnya ada 3 manfaat media sosial dalam proses belajar mengajar di tengah pandemi Covid-19 menurut mereka, yaitu:

a. Mengurangi Beban Guru

Pembelajaran secara tatap muka mengharuskan guru hadir di tengahtengah siswa. Dengan adanya media sosial ini, guru tidak perlu memberikan materi, tugas, bahkan evaluasi datang ke dalam kelas. Cukup memberikan tugas melalui media sosial seperti Whatsapp, Facebook, bahkan Youtube.

b. Mengasah Kemampuan IT

Selama ini murid dan orang tua terlalu gagap terhadap teknologi. Mereka belum terlalu paham tentang kegunaan media sosial. Sepengetahuan mereka, media sosial hanya digunakan untuk menyebar berita kehidupan artis, politik, atau berita hoax. Akibat pandemi ini, pengetahuan mereka terhadap teknologi informasi dan komunikasi mulai terasah. Mereka dapat menggunakan itu sebagai media belajar. Guru memberikan tugas di media tersebut, bahkan murid dapat mencari jawaban di media tersebut.

c. Mengajarkan Kemandirian Siswa

Pandemi saat ini mengharuskan siswa belajar dari rumah. Penonaktifan pembelajaran secara tatap muka membuat opsi pembelajaran jarak jauh sebagai langkah terakhir. Hal tersebut menjadikan seorang siswa harus memiliki dan menguasai sarana dan prasarana penunjang media sosial. Selain itu, media sosial mengajarkan sikap kemandirian siswa. Siswa dituntut belajar tanpa didampingi oleh seorang guru. Siswa harus menyelesaikan tugas secara individu. Bahkan siswa pula yang mencari materi tersebut. Guru hanya memberikan materi atau tugas secara garis besar dan siswa yang menguraikan materi atau tugas tersebut. ${ }^{28}$ pukul 10.30 .

${ }^{28}$ Hasil Wawancara dengan M. Irfan Fandi dan Orang Tua pada tanggal 25 Agustus 2020 


\section{Manfaat Media Sosial bagi Guru dalam Proses Pembelajaran MI Al- Iman di tengah Wabah Covid-19}

Sesuai dengan arahan Kemendikbud, MI Al-Iman juga menerapkan pembelajaran jarak jauh/daring. Aktivitas di sekolah hanya dilakukan oleh dewan guru dan staff. Siswa tidak diperkenankan datang ke sekolah. Terkecuali keperluan mendesak seperti keperluan surat menyurat dan keperluan tandatangan.

Proses belajar dengan menggunakan media sosial bagi dewan guru MI Al-Iman adalah sebuah ketentuan yang dipaksakan. Secara sarana prasarana dan mental belum mampu. Sebab selama ini media sosial bagi siswa MI Al-Iman bukan media untuk belajar melainkan media bermain. Hal tersebut seperti yang dijelaskan oleh Bapak Bonari S,Pd.I., selaku kepala MI Al-Iman:

"Kami merasa seperti dipaksa, harus. Padahal pembelajaran dengan internet selama ini hanya satu dua kali saja. Dan itu untuk kelas-kelas atas. Karena kami tahu sarana dan prasarana yang dimiliki wali murid belum terpenuhi secara merata dan mental pun juga belum mampu.” 29

Beliau meneruskan:

"Kendati sarana terpenuhi, dalam pemanfaatan media internet siswa sekolah dasar selama ini belum diarahkan pada pemanfaatan media sosial dalam proses belajar. Sekedar untuk menonton film kartun di youtube atau bermain game online. Butuh pengawasan dari orang tua.”

Hal senada turut disampaikan oleh Ibu Rafiqah, selaku guru kelas 1 MI Al-Iman. Beliau menyampaikan: “Orang tua harus berperan aktif selama proses pembelajaran dari rumah berlangsung, mengawasi dan mengarahkan mereka." 30

Bagi MI Al-Iman Way Jepara, Media Sosial sangat membantu proses belajar di tengah pandemi ini. Guru dapat menyampaikan materi, memberikan tugas, menyapa anak murid, dan mengawasi mereka melalui media sosial.

\footnotetext{
${ }^{29}$ Hasil Wawancara dengan Bapak Bonari pada tanggal 25 Agustus 2020 pukul 09.00.

${ }^{30}$ Hasil Wawancara dengan Ibu Rafiqah pada tanggal 27 Agustus 2020 pukul 09.30.
} 
Melalui wawancara dengan beberapa guru di MI Al-Iman Way Jepara penulis dapat merangkum wawancara itu dalam beberapa uraian singkat tentang pemanfaatan media sosial di tengah pandemi Covid-19 ini. Adapun uraian tersebut diantaranya:

a. Media Sosial Membantu Guru dalam Menyampaikan Materi dan Tugas kepada Murid

Di tengah pandemi wabah Virus Corona, pembelajaran tatap muka ditiadakan untuk sementara dan menggantikannya dengan pembelajaran jarak jauh. Begitu pula yang dilakukan di MI Al-Iman Way Jepara yang menjalankan proses belajar dan mengajar jarak jauh. Dalam proses pembelajaran jarak jauh ini guru memanfaatkan media sosial sebagai media belajarnya. Dengan menggunakan media sosial, guru dapat menyampaikan materi belajar dan bahkan memberikan tugas kepada mereka.

Materi yang disampaikan sebatas materi ringan, dan menekankan pada kecerdasan motorik siswa. Semisal tata cara hidup sehat dan berbakti kepada orang tua. Begitu pula terhadap tugas, guru memberikan tugas tidak lepas dari tata cara hidup sehat ditengah pandemi Covid-19. Guru memberikan tugas kepada murid tentang bagaimana cara menjaga diri agar selalu bersih dan sehat. Jawaban tugas tersebut berupa video singkat.

Media sosial tidak semuanya dapat dimanfaatkan oleh guru, hanya media sosial tertentu saja, seperti facebook, whatsapp, dan youtube. Hal tersebut mengingat kemampuan penguasaan media sosial oleh guru dan orang tua pada media sosial yang dianggap ringan dan selalu digunakan setiap harinya.

\section{b. Media Sosial Membantu Guru dalam Mengawasi Murid}

Akibat pembelajaran jarak jauh kesenjangan antara guru dan murid sangat terasa. Guru dan murid yang biasanya dipertemukan dalam satu ruangan, kini mereka harus terpisah. Aktivitas murid yang biasanya dapat diperhatikan oleh guru, kini guru tidak tahu apa yang mereka 
lakukan. Apakah mereka belajar atau bermain. Kendati pembelajaran jarak jauh, pengawasan guru kepada murid tetap harus dilakukan. Guru harus memantau aktivitas belajar murid.

Di MI Al-Iman, pengawasan murid oleh guru dilakukan dengan menggunakan media sosial. Ketika hari aktif belajar, guru mengabsen siswa satu per satu dan memastikan para siswa ada di sana. Ketika terdapat salah satu siswa yang belum diketahui keberadaannya, maka guru akan menghubungi orang tuanya dan menanyakan keadaan anaknya tersebut. Setelah semua murid sudah siap untuk belajar, maka guru akan memulai memberikan materi atau tugas.

Guru juga selalu memantau kegiatan murid selama di rumah dengan meminta orang tua mereka untuk memberikan penjelasan terkait aktivitas anak didiknya. Guru turut memberikan motivasi kepada orang tua agar senantiasa gigih dalam mendampingi anak-anak mereka belajar di rumah. Tidak membiarkan mereka lepas begitu saja sehingga ketika belajar secara tatap muka kembali dibuka mereka dapat menceritakan pengalaman mereka ketika belajar dari rumah. ${ }^{31}$

\section{Kesimpulan}

Manfaat media sosial di tengah wabah Virus Corona sangat dirasakan oleh guru, orang tua, dan murid. Proses pembelajaran tidak mengharuskan murid bertatap muka dengan guru di dalam satu ruangan. Manfaat media sosial meliputi mengurangi beban guru, mengasah kemampuan IT, mengajarkan kemandirian siswa, membantu guru menyampaikan materi dan memberkan tugas kepada murid, dan membantu guru dalam mengawasi murid. Dalam pemanfaatannya, masih terdapat beberapa kekurangan seperti guru yang belum menguasai media sosial, murid yang belum terbiasa dengan pembelajaran menggunakan media sosial. Secara umum, media sosial membantu proses pembelajaran di tengah wabah Covid19 ini. Salah satu pemanfaatan media sosial yang dapat dijadikan sebagai referensi 2020.

${ }^{31}$ Hasil Wawancara dengan Dewan Guru MI Al-Iman Way Jepara tanggal 01 September 
adalah pemanfaatan media sosial yang diterapkan di MI Al-Iman. Kendati terkendala sarana dan prasarana serta jaringan internet yang masih lemah, namun proses pembelajaran dapat dilakukan dengan memanfaatkan media sosial. Hal tersebut telah disampaikan oleh kepala MI AL-Iman, dewan guru, wali murid, dan murid. 


\section{DAFTAR PUSTAKA}

Aji, Rizqon Halal Syah. “SALAM: Jurnal Sosial \& Budaya Syar-i.” Dampak Covid-19 pada Pendidikan di Indonesia: Sekolah, Keterampilan, dan Proses Pembelajaran 7, No. 5 (2020): 395-402.

Arsyad, Azhar. 2013. Media Pembelajaran, Jakarta: PT RajaGrafindo Persada.

Azmi, Zul, Abdillah Arif N, Wardayani. “Akuntabilitas: Jurnal Ilmu Akuntansi.” Memahami Penelitian Kualitatif dalam Akuntansi 11, No. 1 (2018): 2461-1190.

Darmawan, Deni. 2016. Pengembangan E-Learning Teori dan Desain. Bandung: PT Remaja Rosdakarya.

Falahudin, Iwan. “Jurnal Lingkar Widyaiswara,” Pemanfaatan Media dalam Pembelajaran 1, No. 4 (2014): 104-117.

Firman, dan Sari Rahayu Rahman, "Indonesian Journal of Educational Science (IJES)”, Pembelajaran Online di tengah Pandemi Covid-19 2, No. 2 (2020): 81-89

Hanafi, Muhammad. “JOM FISIP.” Pengaruh Penggunaan Media Sosial Facebook Terhadap Motivasi Belajar Mahasiswa FISIP Universitas Riau 3, No. 2 (2016): 1-12.

Istiqlal, Abdul. “Jurnal Kepemimpinan dan Pengurus Sekolah.” Manfaat Media Pembelajaran dalam Proses Belajar dan Mengajar Mahasiswa di Perguruan Tinggi 3, No. 2 (2018): 139-144.

Mulawarman, dan Aldila Dyas Nurfitri. "Buletin Psikolog.” Perilaku Pengguna Media Sosial Beserta Implikasinya Ditinjau dari Perspektif Psikologi Sosial Terapan 25, No. 1 (2017): 36-44.

Nanda B, Cut Nadya, dan Rita Destiwati. “Jurnal Manajemen Komunikasi.” Pola Komunikasi Virtual Grup Percakapan Komunitas Hamur “HAMURinspiring” Di Media Sosial Line 3, No. 1 (2018): 34-50.

Pakpahan, Roida, Yuni Fitriani. "Journal of Information System, Applied, Managemen, Accounting, and Research.” Analisis Pemanfaatan Teknologi Informasi dalam Pembelajaran Jarak Jauh di tengah Pandemi Virus Corona Covid-19 4, No. 2 (2020): 30-37.

Priansa, Donni Juni. 2017. Komunikasi Pemasaran Terpadu. Bandung: Pustaka Setia. 
Pujilestari, Yulita. “Adalah: Buletin Hukum \& Keadilan.” Dampak Positif Pembelajaran Online dalam Sistem Pendidikan Indonesia Pasca Pandemi Covid-19 4, No. 1 (2020): 49-56.

Purwanto, Agus, Rudi Pramono, Maduki Asbari, Priyono Budi Santoso, Laksumi Mayesti Wijayanti, Choi Chi Hyun, Ratna Setyowati Putri. "Edupsycouns Journal: Journal of Education, Psychology and Counseling.” Studi Eksplorasi Dampak Pandemi Covid-19 Terhadap Proses Pembelajaran Online di Sekolah Dasar 2. No. 1 (2020): 27164446.

Putria, Hilna, Luthfi Hamdani Maula, dan Din Azwar Uswatun, "Jurnal Basicedu,” Analisis Proses Pembelajaran Dalam Jaringan (DARING) Masa Pandemi COVID-19 pada Guru Sekolah Dasar 4, No. 4 (2020): 861-872.

Sadikin, Ali, dan Afreni Hamidah, "BIODIK: Jurnal Ilmiah Pendidikan Biologi," Pembelajaran Daring di Tengah Wabah Covid-19 6, No. 2 (2020): 214-224.

Sampurno, Muchammad Bayu Tejo, Tri Cahyo Kusumandyoko, dan Muh Ariffudin Islam. "SALAM: Jurnal Sosial \& Budaya Syar-i.” Budaya Media Sosial, Edukasi Masyarakat dan Pandemi COVID-19 7, No. 6 (2020): 529-542.

Setiadi, Ahmad. “AMIK BSI Karawang,” Pemanfaatan Media Sosial untuk Efektifitas Komunikasi 1, No. 1 (2012).

Setiawan, Adip Rifqi. “Edukasi: Jurnal Ilmu Pendidikan.” Lembaga Kegiatan Literasi Saintifik untuk Pembelajaran Jarak Jauh Topik Penyakit Coronavirus 2019 (Covid-19) 2, No. 1 (2020): 28-37.

Supriatna, Eman. "SALAM: Jurnal Sosial \& Budaya Syar-i. Wabah Corona Virus Disease Covid 19 Dalam Pandangan Islam 7, No. 6 (2020): 555-564.

Wahyono, Poncojari, H. Husamah, dan Anton Setia Budi, “ Jurnal Pendidikan Profesi Guru,” Guru Profesional di Masa Pandemi COVID-19: Review Implementasi, Tantangan, dan Solusi Pembelajaran Daring 1, No. 1 (2020): 51-65.

Widiastuti, Rosarita Niken. Memaksimalkan Penggunaan Media Sosial dalam Lembaga Pemerintah. Jakarta: Direktorat Jenderal Informasi dan Komunikasi Publik, Kementerian Komunikasi dan Informatika, 2018.

Yuliana, "Wellness and Healthy Magazine," Corona Virus Diseases (Covid-19); Sebuah Tinjauan Literatur 2, No. 1 (2020): 187-192. 